\title{
OPTIMIZATION BUILDING ENCLOSURE REDESIGN TO FULFILL NATURAL LIGHTING INTENSITY STANDARD AND OTTV IN SOUTH QUARTER JAKARTA OFFICE BUILDING BASED ON GREENSHIP CRITERIA
}

\author{
${ }^{1}$ Naomi Santoso. ${ }^{2}$ Dr. Ir. Yasmin Suriansyah, MSP. \\ ${ }^{1}$ Student in the Bachelor's (S-1) Study Program in Architecture \\ at Parahyangan Catholic University \\ ${ }^{2}$ Senior lecturer in the Bachelor's (S-1) Study Program in Architecture \\ at Parahyangan Catholic University
}

\begin{abstract}
South Quarter is one of the buildings that applies green building principles located in South Jakarta. Based on the Greenship assessment standards, energy saving efforts to decrease OTTV value on some office floors are considered optimal $(\leq 33.25 \mathrm{~W} / \mathrm{m} 2)$, but haven't occupied the natural lighting intensity standard $(\leq 30 \%)$. Based on the existing design, there are things which can be optimized such as the color selection of floor, ceiling, and envelope material. The lighting optimization will certainly affect the heat that goes into the building, therefore the effort of optimizing South Quarter office façade design for the fulfillment of natural lighting intensity and OTTV value based on the Greenship criteria is important to do.

This research uses descriptive-evaluative research with quantitative-qualitative approach. The evaluative research is done by controlling the building envelope design (simulation method), then observing the effects. These effects are devoted to 2 points, which are natural lighting intensity and OTTV value. The qualitative approach is done by observing the object of study.

By replacing glass material, floor material, adding shading elements and light shelf, the optimization of building envelope design has increased the natural lighting intensity by 14.84-30.71\% to occupy the Greenship criteria, while maintaining the OTTV standard.
\end{abstract}

Key Words: natural lighting intensity, OTTV value, Greenship, material, shading, light shelf.

\section{OPTIMASI REDESAIN SELUBUNG BANGUNAN UNTUK PEMENUHAN STANDAR INTENSITAS PENCAHAYAAN ALAMI DAN NILAI OTTV PADA KANTOR SOUTH QUARTER JAKARTA BERDASARKAN KRITERIA GREENSHIP}

\author{
${ }^{1}$ Naomi Santoso. ${ }^{2}$ Dr. Ir. Yasmin Suriansyah, MSP. \\ ${ }^{1}$ Mahasiswi S1 Program Studi Arsitektur Universitas Katolik Parahyangan \\ ${ }^{2}$ Dosen Pembimbing S1 Program Studi Arsitektur Universitas Katolik Parahyangan
}

\begin{abstract}
Abstrak- South Quarter, adalah salah satu bangunan yang menerapkan prinsip green building yang terletak di Jakarta Selatan. Berdasarkan standar penilaian Greenship, usaha penghematan energi pada bangunan ini untuk menurunkan nilai OTTV pada beberapa lantai kantor sudah optimal $(\leq 33,25 \mathrm{~W} / \mathrm{m} 2)$, namun belum memenuhi standar intensitas pencahayaan alami yang masuk $(\leq 30 \%)$. Apabila dilihat dari desain eksisting, masih ada halhal yang perlu dioptimalkan seperti pemilihan warna lantai, plafon, serta material selubung bangunannya. Pengoptimalan pencahayaan tentunya akan berpengaruh terhadap panas yang masuk ke dalam bangunan juga,
\end{abstract}

${ }^{1}$ Corresponding Author: naomisantoso14@gmail.com 
oleh karena itu upaya Optimasi redesain fasad perkantoran South Quarter untuk pemenuhan intensitas pencahayaan alami maupun nilai OTTV berdasarkan standar Greenship penting untuk dilakukan.

Penelitian ini menggunakan penelitian deskriptif-evaluatif dengan pendekatan kuantitatif-kualitatif. Penelitian evaluatif dilakukan dengan metode simulasi, yaitu dengan melakukan kontrol terhadap desain selubung bangunan, kemudian pengaruh yang muncul akibat simulasi ini akan diamati. Pengaruh tersebut dikhususkan pada 2 poin utama, yaitu pencahayaan alami secara kuantitatif dan nilai OTTV. Pendekatan secara kualitatif dilakukan dengan melakukan observasi pada objek studi.

Dengan melakukan penggantian material kaca, material lantai, penambahan elemen shading, serta penambahan light shelf, Optimasi redesain selubung bangunan berhasil meningkatkan intensitas pencahayaan alami sebesar 14,84-30,71\% untuk pemenuhan standar Greenship, dengan tetap menjaga nilai OTTV sesuai standar.

Kata Kunci: intensitas pencahayaan alami, nilai OTTV, Greenship, material, shading, light shelf.

\section{PENDAHULUAN}

Masyarakat dunia saat ini sedang dilanda isu krisis energi. Meningkatnya kebutuhan energi di seluruh dunia yang tidak didukung dengan ketersediaan energi di bumi menjadi faktor utama yang seringkali diabaikan oleh manusia. Fakta membuktikan bahwa, energi yang dibutuhkan oleh bangunan berperan cukup besar dalam konsumsi energi dunia secara keseluruhan $\left(39,25 \%\right.$ dari total penggunaan energi dunia pada tahun $\left.2017^{2}\right)$. Oleh karena itu, desain sebuah bangunan akan sangat mempengaruhi konsumsi energi di dunia.

Desain bangunan green (green building) mencoba untuk menjawab permasalahan tersebut. Green building saat ini mulai populer di kalangan masyarakat. Hal ini dikarenakan keuntungan yang dapat ditawarkan dari penerapan prinsip bangunan hijau, yaitu penghematan konsumsi energi yang sangat dibutuhkan oleh masyarakat di seluruh dunia saat ini. Dengan penghematan yang dilakukan melalui rancangan bangunan, diharapkan bahwa kelangsungan hidup masyarakat dapat terjamin. Maka dari itu, usaha penghematan konsumsi energi penting di zaman sekarang ini.

Beberapa bangunan di Indonesia juga telah mulai mencoba untuk menerapkan prinsipprinsip desain bangunan hijau yang hemat energi, salah satunya pada bangunan South Quarter yang ada di Jakarta Selatan. Desain fasad pada ruang kantor South Quarter dirancang dengan konstruksi fasad dua lapis atau secondary skin. Lapisan pertama ialah kaca double glass dengan rongga udara di antaranya, kemudian terdapat louvre atau kisi-kisi metal yang berfungsi sebagai secondary skin dalam menangkal panas dari cahaya matahari ${ }^{3}$.
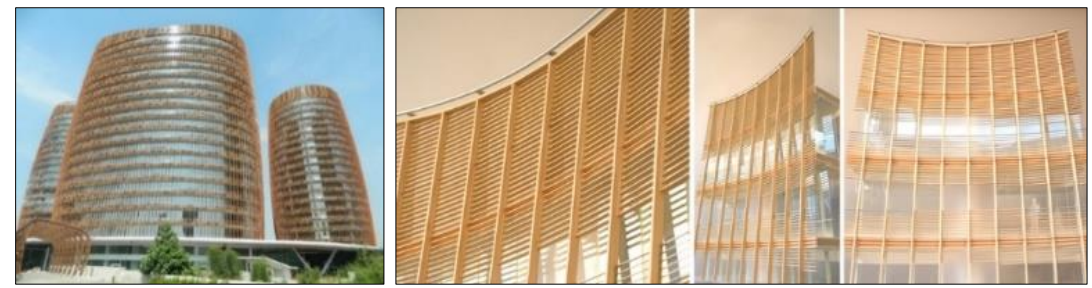

Gambar 1 Gedung Ruang kantor South Quarter dan Desain Fasad Louvre

(Sumber: http://dienersyz.com/investments/ dan http://wkkarchitects.com/south-quarter-1/)

Desain fasad dua lapis ini mengurangi bukaan yang dapat menjadi jalan masuk bagi panas matahari. Akibatnya, panas yang masuk ke dalam bangunan menjadi berkurang sehingga energi yang diperlukan untuk menurunkan temperatur di dalam ruang pun juga berkurang.

\footnotetext{
2 US Energy Information and Administration, "Energy Consumption Estimates by Sector", diakses dari https://www.eia.gov/consumption/, pada tanggal 26 Januari 2018.

${ }^{3}$ Haryandaru, Dipa. "South Quarter, Ruang yang Inspiratif" diakses dari http://www.rei.or.id/newrei/berita-southquarter-ruang-yang-inspiratif.html, pada tanggal 10 Januari 2018.
} 
Dengan demikian, desain fasad ini menurunkan nilai perpindahan termal menyeluruh atau nilai OTTV (Overall Thermal Transfer Value) pada bangunan ruang kantor South Quarter.

Sebelum memulai penelitian ini, penyusun telah melakukan penelitian awal terkait dengan intensitas pencahayaan alami yang diperoleh di dalam ruang kantor South Quarter Jakarta. Hasil dari penelitian tersebut adalah sebagai berikut.

Tabel 1 Hasil Studi Awal terhadap Desain Selubung Bangunan Ruang Kantor South Quarter Jakarta

\begin{tabular}{|c|c|c|c|}
\hline No & Lantai & OTTV & $\begin{array}{c}\text { Rata-Rata Rasio Luas Lantai Kerja dengan Iluminansi } \geq \\
300 \text { lux terhadap Luas Lantai Kerja Keseluruhan }\end{array}$ \\
\hline 1. & M & $29,56 \mathrm{~W} / \mathrm{m}^{2}$ & $17,52 \%$ \\
\hline 2. & 2 & $24,26 \mathrm{~W} / \mathrm{m}^{2}$ & $6,91 \%$ \\
\hline 3. & 11 & $18,17 \mathrm{~W} / \mathrm{m}^{2}$ & $7,74 \%$ \\
\hline 4. & 21 & $29,85 \mathrm{~W} / \mathrm{m}^{2}$ & $8,55 \%$ \\
\hline 5. & $\mathrm{P}$ & $34,74 \mathrm{~W} / \mathrm{m}^{2}$ & $9,30 \%$ \\
\hline
\end{tabular}

(Sumber: Hasil Perhitungan)

Dari tabel di atas, dapat disimpulkan bahwa desain selubung bangunan ruang kantor South Quarter Jakarta belum dapat memenuhi standar penilaian GBCI dalam memasukkan pencahayaan alami ke dalam ruangan (rata-rata rasio luas lantai kerja dengan iluminansi 300 lux terhadap luas lantai kerja keseluruhan $\geq 30 \%$ ) meskipun pada beberapa lantai kantor telah mengoptimalkan perolehan panas yang masuk ke dalam bangunan (nilai OTTV $\leq 33,25 \mathrm{~W} / \mathrm{m}^{2}$ ). Apabila dilihat dari desain selubung bangunan eksisting, masih ada hal-hal yang perlu dioptimalkan seperti pemilihan warna lantai, plafon, serta material selubung bangunannya. Pengoptimalan pencahayaan tentunya akan berpengaruh terhadap panas yang masuk ke dalam bangunan juga, oleh karena itu perlu dicari Optimasi redesain selubung bangunan terhadap pencahayaan alami maupun panas yang masuk.

\section{KAJIAN TEORI}

\subsection{PENCAHAYAAN ALAMI PADA BANGUNAN}

Pencahayaan pada bangunan dapat dicapai melalui beberapa strategi, yaitu sidelighting, toplighting, dan kombinasi dari keduanya. Sidelighting ialah strategi memasukkan pencahayaan ke dalam bangunan melalui elemen vertikal bangunan (dinding).

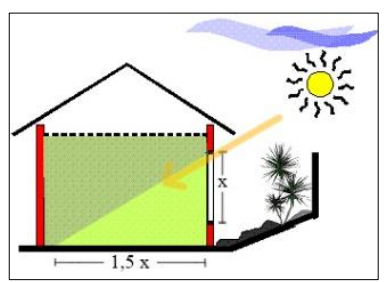

Gambar 2 Ilustrasi Sidelighting pada Bangunan

(Sumber: http://www.rihants.com/2013/11/optimalisasi-pencahayaan-alami.html)

Aturan praktisnya ialah apabila pencahayaan yang masuk melalui elemen vertikal bangunan telah mencapai sekitar 1,5 (satu setengah) kali tinggi bukaan atau jendela maka upaya sidelighting ini dapat dianggap telah efektif. Apabila sidelighting dilakukan pada 
orientasi tunggal, maka pencapaian cakupan pencahayaan di lantai kerja ditargetkan mencapai $15 \%$ pada orientasi ke arah Selatan dan $20 \%$ pada orientasi ke arah Utara. ${ }^{4}$

Terdapat tiga komponen yang diperlukan dalam pencahayaan, yaitu sumber cahaya, distribusi cahaya, dan kontrol cahaya. Apabila ketiga komponen ini diintegrasikan dengan baik, maka optimalisasi penggunaan energi dapat dicapai. ${ }^{5}$

Berikut adalah rekomendasi tingkat iluminansi untuk aktivitas-aktivitas tertentu.

Tabel 2 Rekomendasi Luminas Untuk Berbagai Aktivitas.

\begin{tabular}{|c|c|c|}
\hline Kategori & $\begin{array}{l}\text { Luminans dalam Lux } \\
\text { (Footcandles) }\end{array}$ & Tipe Aktivitas \\
\hline A & $\begin{array}{c}20-30-500^{a} \\
(2-3-5)^{a}\end{array}$ & Area publik dengan kondisi sekitar yang gelap. \\
\hline $\mathrm{B}$ & $\begin{array}{l}50-75-100^{a} \\
(5-7,5-10)^{a}\end{array}$ & $\begin{array}{l}\text { Orientasi sederhana untuk kunjungan yang singkat dan } \\
\text { bersifat sementara. }\end{array}$ \\
\hline $\mathrm{C}$ & $\begin{array}{l}100-150-200^{\mathrm{a}} \\
(10-15-20)^{\mathrm{a}}\end{array}$ & Ruang kerja di mana tugas visual hanya sesekali dilakukan. \\
\hline $\mathrm{D}$ & $\begin{array}{l}200-300-500^{b} \\
(20-30-50)^{b}\end{array}$ & $\begin{array}{l}\text { Kinerja tugas visual dengan kontras tinggi, misalnya } \\
\text { membaca materi printed, hasil ketikan, tulisan tangan } \\
\text { dengan tinta dan xerografi yang bagus; pekerjaan mesin } \\
\text { berkualitas kasar; pemeriksaan biasa; perakitan kasar. }\end{array}$ \\
\hline $\mathrm{E}$ & $\begin{array}{l}500-750-1000^{b} \\
(50-75-100)^{b}\end{array}$ & $\begin{array}{l}\text { Kinerja tugas visual dengan kontras menengah, misalnya, } \\
\text { membaca tulisan tangan pensil dalam ukuran medium, } \\
\text { bahan tidak dicetak dengan baik (poorly printed); pekerjaan } \\
\text { mesin berkualitas menengah; pemeriksaan yang sulit; } \\
\text { perakitan menengah. }\end{array}$ \\
\hline $\mathrm{F}$ & $\begin{array}{l}1000-1500-2000^{b} \\
(100-150-200)^{b}\end{array}$ & $\begin{array}{l}\text { Kinerja tugas visual dengan kontras rendah dan ukurannya } \\
\text { sangat kecil, misalnya membaca tulisan tangan dengan } \\
\text { pensil keras pada kertas berkualitas rendah dan bahan hasil } \\
\text { produksi ulang yang buruk; pemeriksaan yang sangat sulit. }\end{array}$ \\
\hline G & $\begin{array}{l}2000-3000-5000^{b} \\
(200-300-500)^{b}\end{array}$ & $\begin{array}{l}\text { Kinerja tugas visual dengan kontras rendah dan ukurannya } \\
\text { sangat kecil dalam waktu lama, misalnya perakitan halus; } \\
\text { pemeriksaan yang sangat sulit; pekerjaan mesin berkualitas } \\
\text { halus. }\end{array}$ \\
\hline $\mathrm{H}$ & $\begin{array}{l}5000-7500-10.000^{\mathrm{b}} \\
(500-750-1.000)^{\mathrm{b}}\end{array}$ & $\begin{array}{l}\text { Kinerja tugas visual yang sangat berkepanjangan dan } \\
\text { menuntut, misalnya pemeriksaan yang paling sulit; } \\
\text { pekerjaan mesin berkualitas sangat baik; perakitan ekstra } \\
\text { halus. }\end{array}$ \\
\hline I & $\begin{array}{l}10.000-15.000-20.000^{\mathrm{b}} \\
(1.000-1.500-2.000)^{\mathrm{b}}\end{array}$ & $\begin{array}{l}\text { Kinerja tugas visual yang sangat istimewa dengan kontras } \\
\text { yang sangat rendah dan ukurannya yang kecil, misalnya } \\
\text { prosedur pembedahan. }\end{array}$ \\
\hline
\end{tabular}

a pencahayaan merata di seluruh ruangan

${ }^{\mathrm{b}}$ luminans pada tugas visual tertentu, diperoleh dari kombinasi pencahayaan merata dan terarah/lokal (pelengkap)

Sumber: Planning and Designing the Office Environment, 1981.

Istilah-istilah yang terkait dengan pencahayaan alami adalah sebagai berikut: 1) terang langit, 2) langit perencanaan, 3) faktor langit, 4) titik ukur, dan 5) bidang lubang cahaya efektif. Terang langit adalah sumber cahaya yang diambil dalam penghitungan pencahayaan alami, sebaiknya dipilih berdasarkan keadaan langit yang sering dijumpai. Langit perencanaan adalah

\footnotetext{
4 7group dan Bill Reed. 2009. The Integrative Design Guide to Green Building, New Jersey: John Wiley \& Sons, Inc. 225.

${ }^{5}$ Bonda, Penny dan Katie Sosnowchik. 2007. Sustainable Commercial Interiors. New Jersey: John Wiley \& Sons, Inc. 78.
} 
keadaan langit yang dijadikan dasar dalam perhitungan. Sebagai langit perencanaan, ditetapkan: 1) langit biru jernih tanpa awan, atau 2) langit yang seluruhnya tertutup awan abuabu putih. Faktor langit adalah nilai yang digunakan sebagai ukuran kondisi pencahayaan alami pada siang hari. Titik ukur adalah sebuah posisi di dalam ruangan yang digunakan sebagai indikator untuk penghitungan intensitas pencahayaan dalam ruangan. Titik ukur diambil pada ketinggian 0,75 meter di atas lantai. Sendangkan bidang lubang cahaya efektif adalah bidang dinding yang dapat secara efektif memasukkan pencahayaan alami ke dalam ruangan. ${ }^{6}$

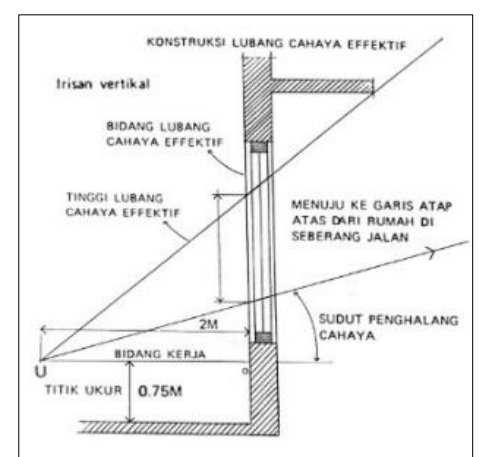

Gambar 3 Konstruksi Lubang Cahaya Efektif

(Sumber: Penerangan Alami Siang Hari dari Bangunan, 1981)

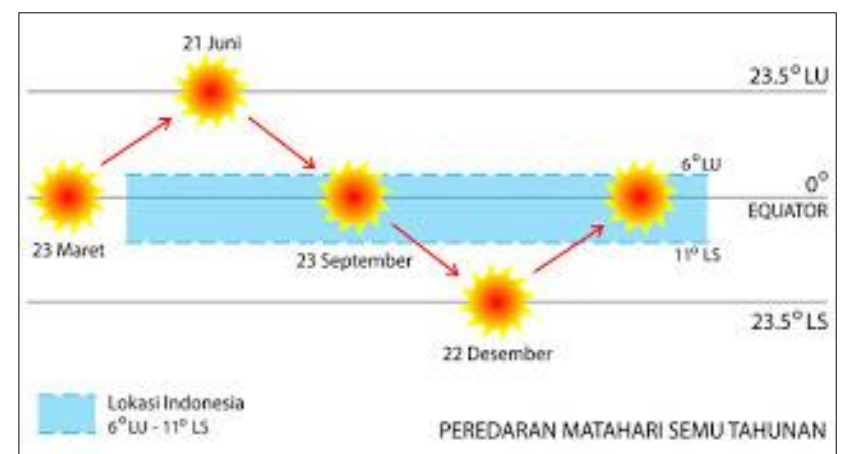

Gambar 4 Peredaran Matahari Semu Tahunan di Indonesia

(Sumber: http://detsunote.blogspot.co.id/2013/01 /menentukan-arah-mata-angin-dengan.html)

Desain pencahayaan alami pada suatu bangunan dapat didasarkan pada standar rasio antara luas kaca/bidang transparan (besar bukaan) terhadap luas lantai, yaitu minmal sebesar 10\%. Namun demikian, standar ini tidak dapat dijadikan patokan utama untuk memperoleh pencahayaan alami yang memuaskan karena masuknya pencahayaan alami tidak hanya dipengaruhi oleh luas bukaan, melainkan juga bentuk dan perletakan bukaan tersebut. ${ }^{7}$ Sumber lain dari Keputusan Menteri Kesehatan tahun 2001 untuk Lingkungan Kerja Perkantoran dan Industri menyebutkan bahwa luas jendela, kisi-kisi atau dinding gelas kaca untuk masuknya cahaya minimal $1 / 6$ kali luas lantai. ${ }^{8}$

Menurut Firtri Rahmadina, dkk, upaya peningkatan intensitas pencahayaan alami dapat dilakukan dengan cara berikut ini: 1) melakukan modifikasi terhadap shading device, 2) melakukan modifikasi terhadap warna material, serta 3) membuat light shelf. Dengan melakukan modifikasi terhadap shading device, tentunya pencahayaan yang masuk akan berubah tergantung desain elemen penghalang tersebut. Sedangkan modifikasi terhadap warna material akan mempengaruhi reflektansi dan absorbsi dari masing-masing material tersebut terhadap cahaya matahari yang datang. ${ }^{9}$

\footnotetext{
${ }^{6}$ Direktorat Jenderal Ciptakarya. 1981. Penerangan Alami Siang Hari dari Bangunan, Bandung: Yayasan Lembaga Penyelidikan Masalah Bangunan. 1.

7 Direktorat Jenderal Ciptakarya. 1981. Penerangan Alami Siang Hari dari Bangunan, Bandung: Yayasan Lembaga Penyelidikan Masalah Bangunan. 16.

${ }^{8}$ Keputusan Menteri Kesehatan Republik Indonesia Nomor 1405/MENKES/SK/XI/2002 tentang Persyaratan Kesehatan Lingkungan Kerja Perkantoran dan Industri. 11.

${ }^{9}$ Rahmadiina, Fitri, dkk. TT. "Optimalisasi Kinerja Pencahayaan Alami pada Kantor (Studi Kasus: Plasa Telkom Blimbing Malang)", Malang: Universitas Brawijaya. 7.
} 


\subsection{NILAI OTTV}

Nilai OTTV (Overall Thermal Transfer Value) ialah nilai perpindahan termal menyeluruh pada dinding luar yang memiliki arah atau orientasi tertentu. Perhitungan nilai ini dapat dilakukan dengan menggunakan persamaan berikut. ${ }^{10}$

$\mathrm{OTTV}=\alpha\left[\left(\mathrm{U}_{w} \times(1-\mathrm{WWR})\right] \times \mathrm{TD}_{\mathrm{EK}}+(\mathrm{SC} \times \mathrm{WWR} \times \mathrm{SF})+\left(\mathrm{U}_{\mathrm{f}} \times \mathrm{WWR} \times \Delta \mathrm{T}\right)\right.$

di mana:

OTTV = nilai perpindahan termal menyeluruh pada dinding luar yang memiliki arah atau satu orientasi tertentu $\left(\mathrm{Watt} / \mathrm{m}^{2}\right)$

$\alpha=$ absorbtansi radiasi matahari

$\mathrm{U}_{\mathrm{w}} \quad=$ transmitansi termal dinding tak tembus cahaya $\left(\mathrm{W} / \mathrm{m}^{2} . \mathrm{K}\right)$

WWR = perbandingan luas jendela dengan luas seluruh dinding luar pada orientasi yang ditentukan

$\mathrm{TD}_{\mathrm{EK}}=$ beda temperatur ekuivalen $(\mathrm{K})$

$\mathrm{SC} \quad=$ koefisien peneduh dari sistem fenetrasi (shading coefficient)

$\mathrm{SF} \quad=$ faktor radiasi matahari $\left(\mathrm{W} / \mathrm{m}^{2}\right)$

$\mathrm{U}_{\mathrm{f}} \quad=$ transmitansi termal fenetrasi $(\mathrm{W} / \mathrm{m} 2 . \mathrm{K})$

$\Delta \mathrm{T} \quad=$ beda temperatur perencanaan antara bagian luar dan bagian dalam (diambil $5 \mathrm{~K}$ )

Persamaan di atas dapat diturunkan menjadi persamaan berikut.

di mana:

$$
\text { OTTV }=\frac{\left(\alpha \times \mathrm{U}_{\mathrm{w}} \times \mathrm{Aw} \times \mathrm{TDek}\right)+(\mathrm{Uf} \times \mathrm{Af} \times \Delta \mathrm{T})+(\mathrm{SF} \times \mathrm{Af} \times \mathrm{SC})}{\mathrm{Ai}}
$$

Aw = Luas dinding masif pada orientasi tersebut

Af = Luas dinding transparan pada orientasi tersebut

$\mathrm{Ai} \quad=$ Luas total seluruh dinding pada orientasi tersebut

Sedangkan untuk menghitung nilai OTTV rata-rata seluruh dinding luar dapat menggunakan persamaan berikut.

di mana:

$$
O T T V=\frac{\left(\mathrm{A}_{01} \times \mathrm{OTTV}_{1}\right)+\left(\mathrm{A}_{02} \times \mathrm{OTTV}_{2}\right)+\ldots \ldots \ldots \ldots \ldots+\left(\mathrm{A}_{0 \mathrm{i}} \times \mathrm{OTTV}_{\mathrm{i}}\right)}{\mathrm{A}_{01}+\mathrm{A}_{02}+\ldots \ldots \ldots \ldots \ldots \mathrm{A}_{0 \mathrm{i}}}
$$

$\mathrm{A}_{0 \mathrm{i}} \quad=$ luas dinding pada bagian dinding luar $\mathrm{i}\left(\mathrm{m}^{2}\right)$. Luas ini termasuk semua permukaan dinding tak tembus cahaya dan luas permukaan jendela yang terdapat pada bagian dinding tersebut

$\mathrm{OTTV}_{\mathrm{i}}=$ nilai perpindahan termal menyeluruh pada bagian dinding i sebagai hasil perhitungan dengan menggunakan persamaan sebelumnya (penghitungan nilai OTTV pada orientasi tertentu)

Nilai shading coefficient di atas sangat dipengaruhi oleh elemen yang dapat menciptakan pembayangan pada bangunan. Berikut ialah beberapa strategi untuk menciptakan pembayangan pada bangunan. ${ }^{11}$

\begin{tabular}{|c|c|c|}
\hline No & Strategi Pembayangan & Keterangan \\
\hline 1. & Horizontal overhang & $\begin{array}{ll}\text { - } & \text { Konstruksi mudah } \\
\text { - } & \text { Efektif untuk menghalangi cahaya matahari dengan sudut tinggi } \\
\text { - } & \text { Tidak efektif untuk menghalangi cahaya matahari dari Timur dan Barat } \\
& \text { yang bersudut rendah } \\
\text { - } & \text { Membutuhkan perawatan (daun jatuh dan kotoran burung) }\end{array}$ \\
\hline
\end{tabular}

Tabel 3 Strategi Pembayangan pada Bangunan

10 SNI 03-6389-2000 Konservasi Energi Selubung Bangunan pada Bangunan Gedung. 4.

11 Building and Construction Authority. 2010. Building Planning and Massing, Green Platinum Series. 46. 


\begin{tabular}{|c|c|c|}
\hline 2. & $\begin{array}{l}\text { Horizontal overhang } \\
\text { below window head }\end{array}$ & $\begin{array}{ll}\text { - } & \text { Konstruksi mudah } \\
\text { - } & \text { Efektif untuk menghalangi cahaya matahari dengan sudut tinggi } \\
\text { - } & \text { Berfungsi juga sebagai light-shelf dan memberikan cahaya difus ke } \\
\text { dalam bangunan } \\
\text { - } \quad \text { Tidak efektif untuk menghalangi cahaya matahari dari Timur dan Barat } \\
\text { yang bersudut rendah } \\
\text { - } \quad \text { Membutuhkan perawatan (daun jatuh dan kotoran burung) }\end{array}$ \\
\hline 3. & $\begin{array}{l}\text { Multiple } \\
\text { overhangs }\end{array}$ & $\begin{array}{l}\text { - } \quad \text { Vision panel menghalangi cahaya matahari dengan sudut tinggi } \\
\text { - } \quad \text { Mengekspos sebagian kecil bukaan transparan untuk memasukkan } \\
\text { cahaya matahari } \\
\text { - } \quad \text { Dapat berfungsi sebagai small light-shelf } \\
\text { - } \quad \text { Tidak efektif untuk menghalangi cahaya matahari dari Timur dan Barat } \\
\text { yang bersudut rendah } \\
\text { - Membutuhkan perawatan lebih }\end{array}$ \\
\hline 4. & Louvered overhang & $\begin{array}{l}\text { - } \quad \text { Efektif untuk menghalangi cahaya matahari dengan sudut tinggi } \\
\text { - } \quad \text { Membutuhkan perawatan lebih karena bentuknya yang rumit } \\
\text { - } \quad \text { Tidak efektif untuk menghalangi cahaya matahari dari Timur dan Barat } \\
\text { yang bersudut rendah }\end{array}$ \\
\hline 5. & Louvered screen & $\begin{array}{l}\text { - Menghalangi cahaya matahari dari Timur dan Barat hanya pada area } \\
\text { yang cukup tinggi } \\
\text { - Mengekspos sebagian kecil bukaan transparan untuk memasukkan } \\
\text { cahaya matahari } \\
\text { - Membutuhkan perawatan lebih karena bentuknya yang rumit }\end{array}$ \\
\hline 6. & $\begin{array}{l}\text { Full-height } \\
\text { screen }\end{array}$ & $\begin{array}{l}\text { - Menghalangi cahaya matahari dari Timur dan Barat } \\
\text { - } \quad \text { Memantulkan cahaya difus secara efektif untuk pencahayaan alami } \\
\text { dalam bangunan } \\
\text { - } \\
\text { - Membutuhkan perawatan lebih karena bentuknya yang rumit } \\
\text { Menghalangi potensi view ke luar bangunan }\end{array}$ \\
\hline
\end{tabular}

(Sumber: Building Planning and Massing, 2010)

Menurut Sandra Loekita, terdapat beberapa poin penting yang dapat mempengaruhi nilai OTTV, yaitu: 1) semakin besar WWR suatu gedung, semakin besar pula nilai OTTV karena semakin besar jendela maka radiasi matahari dan konduksi panas yang masuk akan lebih besar, 2) mutu bahan dan warna selubung bangunan ( $\alpha$ dan SC) sangat berpengaruh terhadap besarnya nilai OTTV, serta 3 ) pemilihan bentuk denah akan sangat mempengaruhi pemakaian energi. ${ }^{12}$

Menurut Yurio Provandi, faktor yang perlu diperhatikan agar dapat menjaga nilai OTTV sesuai dengan standar adalah pemilihan material dan warna dinding, serta pemberian overstek/teritisan pada bukaan kaca. Material dan warna dinding yang dipilih sebaiknya memiliki nilai absorbtansi radiasi matahari yang rendah agar penyerapan radiasi matahari oleh dinding rendah. Sedangkan dengan adanya overstek/teritisan pada bukaan, maka radiasi matahari yang masuk dapat berkurang karena adanya penghalang tersebut. ${ }^{13}$

\subsection{GREENSHIP}

Standar Greenship ialah tolok ukur yang digunakan di Indonesia untuk memberi penilaian terhadap tingkat keberhasilan suatu bangunan dalam menerapkan prinsip-prinsip green building atau bangunan hijau yang ramah lingkungan sejak tahap perencanaan,

\footnotetext{
12 Loekita, Sandra. 2006. "Analisis Konservasi Energi Melalui Selubung Bangunan" dalam Dimensi Teknik Sipil 8(2): 98 , September.

${ }^{13}$ Sholichin, Yurio Provandi. 2012. "Pengaruh Material Dinding terhadap Nilai OTTV pada Berbagai Orientasi Bangunan”, Depok: Universitas Indonesia. 68.
} 
pembangunan, pengoperasian, sampai pemeliharaannya. Seperti yang telah diuraikan sebelumnya, terdapat 6 (enam) kategori utama pada standar yang ditetapkan GBCI ini, yaitu: a) Appropriate Site Development/ASD (tepat guna lahan), b) Energy Efficiency and Conservation/EEC (efisiensi dan konservasi energi), c) Water Conservation/WAC (konservasi air), d) Material Resources and Cycle/MRC (sumber dan siklus material), e) Indoor air health and comfort/IHC (kualitas udara dan kenyamanan ruangan), f) Building and Environment Management/BEM (manajemen lingkungan bangunan).

\section{METODA PENELITIAN}

Penelitian ini menggunakan penelitian deskriptif-evaluatif dengan pendekatan kuantitatif-kualitatif. Penelitian evaluatif dilakukan dengan metode simulasi, yaitu dengan melakukan kontrol terhadap desain selubung bangunan, kemudian pengaruh yang muncul akibat simulasi ini akan diamati. Pengaruh tersebut dikhususkan pada 2 poin utama, yaitu pencahayaan alami secara kuantitatif dan nilai OTTV. Pendekatan secara kualitatif dilakukan dengan melakukan observasi pada objek studi.

\section{ANALISA}

\subsection{KETERKAITAN ANTARA GREEN BUILDING, PENCAHAYAAN ALAMI, DAN NILAI OTTV}

Hadirnya pencahayaan (light) dalam sebuah bangunan tidak dapat dipisahkan dengan keikutsertaan energi panas (heat). Baik pencahayaan alami maupun buatan, keduanya selalu muncul bersamaan dengan energi panas. Menurut 7Group dan Bill G. Reed, pencahayaan buatan pada bangunan mengonsumsi 50\% dari keseluruhan konsumsi listrik, dan $40 \%$ lainnya dikonsumsi untuk mendinginkan ruangan ${ }^{14}$. Dengan demikian, dapat disimpulkan bahwa konsumsi energi listrik dalam bangunan didominasi oleh pencahayaan buatan dan upaya pendinginan bangunan.

Pencahayaan sangat erat kaitannya dengan HVAC. Menurut Penny Bonda dan Katie Sosnowchik, prinsip yang perlu diingat ialah bahwa setiap penghematan 1 (satu) Watt energi untuk pencahayaan, maka konsumsi energi untuk HVAC pun akan berkurang sebesar $1 / 4$ Watt. ${ }^{15}$

Peningkatan pemanfaatan pencahayaan alami juga dapat meningkatkan produktivitas kerja karyawan. Tidak ada standar untuk mengukur peningkatan produktivitas ini, namun terdapat 4 (empat) aspek yang berkontribusi secara signifikan dalam mempengaruhi produktivitas kerja karyawan yaitu: (1) peningkatan kontrol ventilasi, (2) peningkatan kontrol temperatur, (3) peningkatan kontrol pencahayaan buatan, dan (4) peningkatan kontrol pencahayaan alami ${ }^{16}$. Dengan demikian, aspek pencahayaan maupun OTTV (perpindahan termal yang berpengaruh terhadap kontrol temperatur ruangan) menyumbang porsi yang cukup besar dalam meningkatkan produktivitas kerja karyawan, sekaligus dalam penghematan energi.

\subsection{POPULASI DAN SUMBER DATA PENELITIAN}

Penelitian ini dilakukan dengan menggunakan sampel data pada beberapa lantai ruang kantor South Quarter. Pengambilan sampel secara garis besar dilakukan dengan mengambil lantai dengan tipe karakteristik yang berbeda. Lantai dengan denah tipikal pada ruang kantor

\footnotetext{
${ }^{14} 7$ group dan Bill Reed. 2009. The Integrative Design Guide to Green Building, New Jersey: John Wiley \& Sons, Inc. 21.

${ }^{15}$ Bonda, Penny dan Katie Sosnowchik. 2007. Sustainable Commercial Interiors, New Jersey: John Wiley \& Sons, Inc. 79.

${ }^{16}$ Browning, William D., dkk. 2006. Green Office Buildings, A Practical Guide to Development, Washington D.C.: Urban Land Institute. 42.
} 
ini yaitu lantai 2 (dua) sampai dengan 21 (dua puluh satu), sehingga untuk sampel diambil lantai dengan denah tipikal paling bawah (lantai 2), tengah (lantai 11), dan paling atas (lantai 21), karena tipe karakteristik desain selubung bangunannya yang berbeda. Lantai dengan tipe karakteristik selain ketiga sampel di atas pada tower ini ialah lantai M (mezzanine) yang memilik teritisan cukup panjang dan lantai $\mathrm{P}$ (penthouse) yang memiliki ketinggian floor to floor lebih tinggi dari lantai lainnya. Meskipun secara fisik lantai-lantai pada bangunan South Quarter memiliki desain selubung bangunan dengan sudut kemiringan yang berbeda-beda, namun dalam penelitian ini, diambil sampel dari karakteristik lantai yang kurang lebih sama.

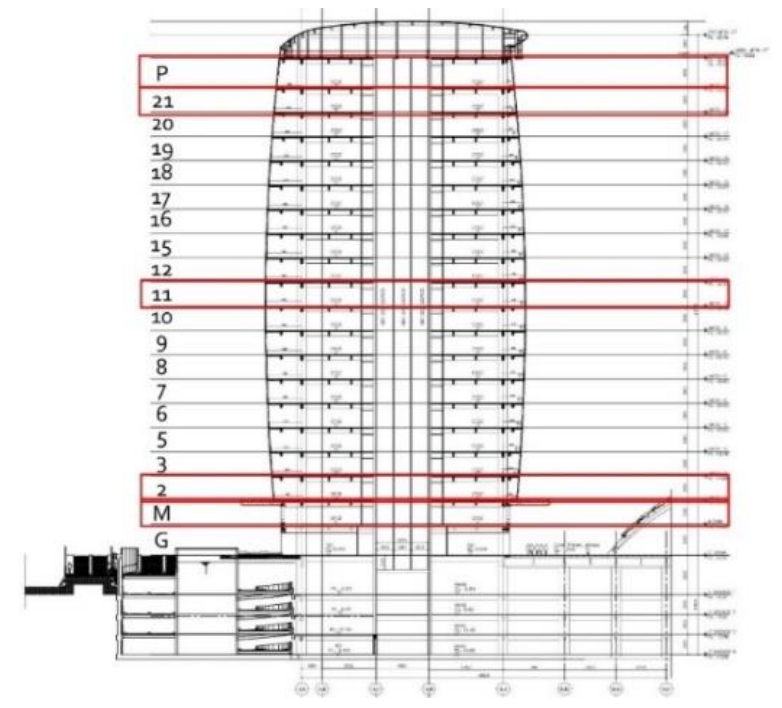

Gambar 5 Potongan Tower dan Pemilihan Lantai untuk Simulasi Pencahayaan

Pengukuran pencahayaan pun dilakukan pada bulan-bulan yang berbeda untuk melihat ragam pengaruh yang dapat terjadi pada bulan-bulan tersebut. Bulan Maret dan September adalah bulan peralihan pada gerak semu tahunan matahari, sehingga bulan untuk simulasi pencahayaan dilakukan berjarak dari kedua bulan tersebut untuk memperoleh kondisi langit yang lebih stabil dan beragam.

\begin{tabular}{|c} 
Januari Februari Maret April Mei Juni Juli \\
Peralihan
\end{tabular}$\underset{\substack{\text { Agustus September Oktober } \\
\text { Peralihan }}}{\text { November Desember }}$

Gambar 6 Pemilihan Bulan untuk Simulasi Pencahayaan

Waktu dilakukannya simulasi pun dipilih berdasarkan pertimbangan bahwa jam kerja di ruang kantor South Quarter yaitu pukul 08.00-17.00 WIB. Dengan demikian, untuk memperoleh data yang valid, simulasi dilakukan dengan interval 2 (dua) jam.

\begin{tabular}{|c|c|c|c|c|c|c|c|c|}
\hline 08.00 & 09.00 & 10.00 & 11.00 & 12.00 & 13.00 & 14.00 & 15.00 & 16.00 \\
\hline
\end{tabular}

Gambar 7 Pemilihan Waktu untuk Simulasi Pencahayaan

Metode simulasi pencahayaan pun akan dilakukan dengan program Velux Daylight Visualizer 3, dengan mensimulasikan kondisi langit cerah (sunny) dengan kekuatan penerangan 10.000 lux. 


\subsection{KONDISI EKSISTING DESAIN SELUBUNG BANGUNAN KANTOR SOUTH QUARTER}

Berikut adalah rangkuman hasil pengamatan nilai OTTV dan intensitas pencahayaan alami eksisting di kantor South Quarter.

Tabel 4 Rangkuman Hasil Pengamatan Nilai OTTV dan Intensitas Pencahayaan Alami Eksisting

\begin{tabular}{|c|c|c|c|}
\hline No & Lantai & OTTV & $\begin{array}{c}\text { Rata-Rata Rasio Luas Lantai Kerja dengan Iluminansi } \geq 300 \\
\text { lux terhadap Luas Lantai Kerja Keseluruhan }\end{array}$ \\
\hline 1. & M & $29,56 \mathrm{~W} / \mathrm{m}^{2}$ & $17,52 \%$ \\
\hline 2. & 2 & $24,26 \mathrm{~W} / \mathrm{m}^{2}$ & $6,91 \%$ \\
\hline 3. & 11 & $18,17 \mathrm{~W} / \mathrm{m}^{2}$ & $7,74 \%$ \\
\hline 4. & 21 & $29,85 \mathrm{~W} / \mathrm{m}^{2}$ & $8,55 \%$ \\
\hline 5. & $\mathrm{P}$ & $34,74 \mathrm{~W} / \mathrm{m}^{2}$ & $9,30 \%$ \\
\hline & \multirow{2}{*}{\multicolumn{3}{|c|}{$\begin{array}{l}\text { sudah memenuhi standar maksimum perolehan poin Greenship } \\
\text { belum memenuhi standar perolehan poin Greenship } \\
\text { sudah memenuhi standar perolehan poin Greenship namun belum maksimal }\end{array}$}} \\
\hline & & & \\
\hline
\end{tabular}

(Sumber: Hasil Perhitungan dan Simulasi)

Selubung bangunan lantai mezzanine didesain menggunakan material glazing yang berbeda dari lantai-lantai lainnya, yaitu $12 \mathrm{~mm}$ clear float glass. Pemilihan material glazing ini sangat berpengaruh terhadap nilai OTTV dan pencahayaan alami yang masuk ke dalam bangunan. Selain itu, adanya kantilever peneduh yang panjang (6 meter) juga sangat mempengaruhi nilai OTTV maupun intensitas pencahayaan alami yang diperoleh. Nilai OTTV pada lantai ini telah memenuhi standar, namun intensitas pencahayaan alami dari desain selubung bangunan eksisting pada lantai mezzanine belum memenuhi standar yang ditetapkan oleh GBCI.

Selubung bangunan lantai 2, 11, dan 21 didesain menggunakan material kaca double glass dengan rongga udara di antaranya. Nilai OTTV pada ketiga lantai tersebut sudah memenuhi standar (jauh melampaui standar yang ditetapkan), namun intensitas pencahayaan alami yang masuk belum memenuhi standar yang ditetapkan oleh GBCI.

Selubung bangunan lantai penthouse didesain menggunakan material glazing seperti pada lantai 2, 11, maupun 21, yaitu dengan kaca double glass dengan rongga udara di antaranya. Nilai OTTV pada lantai penthouse sudah memenuhi standar SNI $\left(35 \mathrm{Watt} / \mathrm{m}^{2}\right)$, namun belum dapat memperoleh poin maksimum ( 2 poin) berdasarkan standar GBCI, karena lebih sedikitnya shading pada desain selubung bangunan lantai ini. Selain itu, intensitas pencahayaan alami yang masuk juga belum memenuhi standar yang ditetapkan oleh GBCI.

\subsection{SIMULASI DESAIN SELUBUNG BANGUNAN}

\subsubsection{MODIFIKASI 1: PERUBAHAN MATERIAL GLAZING}

Berikut adalah material glazing eksisting yang digunakan.

\section{Tabel 5 Spesifikasi Material Glazing Eksisting}

\begin{tabular}{|ll|}
\hline \multicolumn{1}{|c|}{ Lantai GF-Mezzanine } \\
\hline$\circ$ & Tipe kaca: $12 \mathrm{~mm}$ clear float glass (reflective finished) \\
$\circ$ & $\Delta T=5$ \\
$\circ$ & Thickness $=12 \mathrm{~mm}$ \\
$\circ$ & $\mathrm{SC}=0,83$ \\
$\circ$ & U value $=5,60$ \\
\hline
\end{tabular}




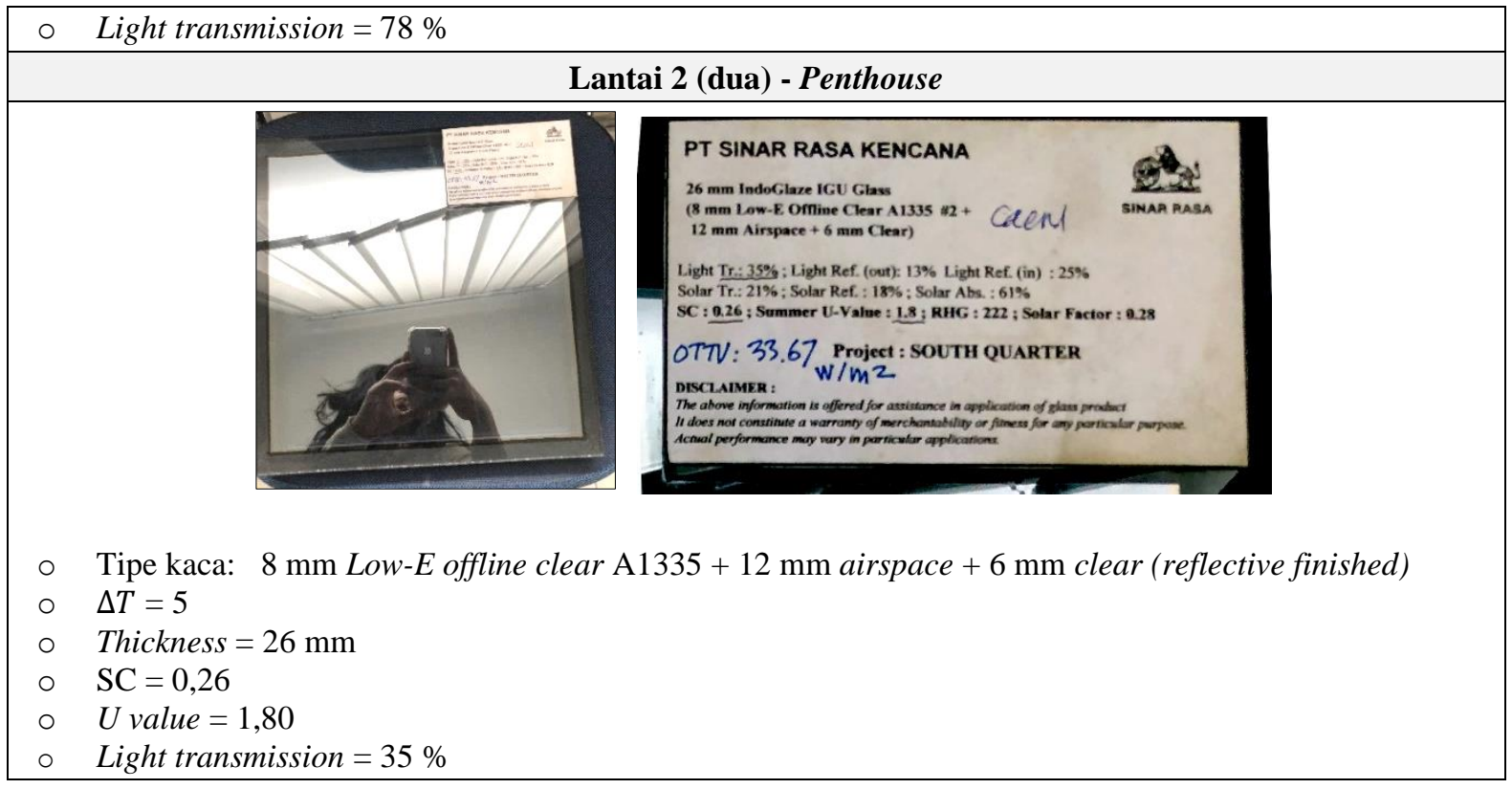

Setelah diteliti dan dilakukan perhitungan, ternyata nilai OTTV dari penggunaan kedua material kaca ini sudah cukup baik, namun intensitas pencahayaan alami yang masuk ke dalam ruangan masih di bawah standar. Dengan demikian, modifikasi yang dilakukan ialah dengan mengubah material glazing yang memiliki nilai light transmission lebih tinggi.

Berikut adalah material glazing untuk modifikasi.

Tabel 6 Spesifikasi Material Glazing untuk Modifikasi

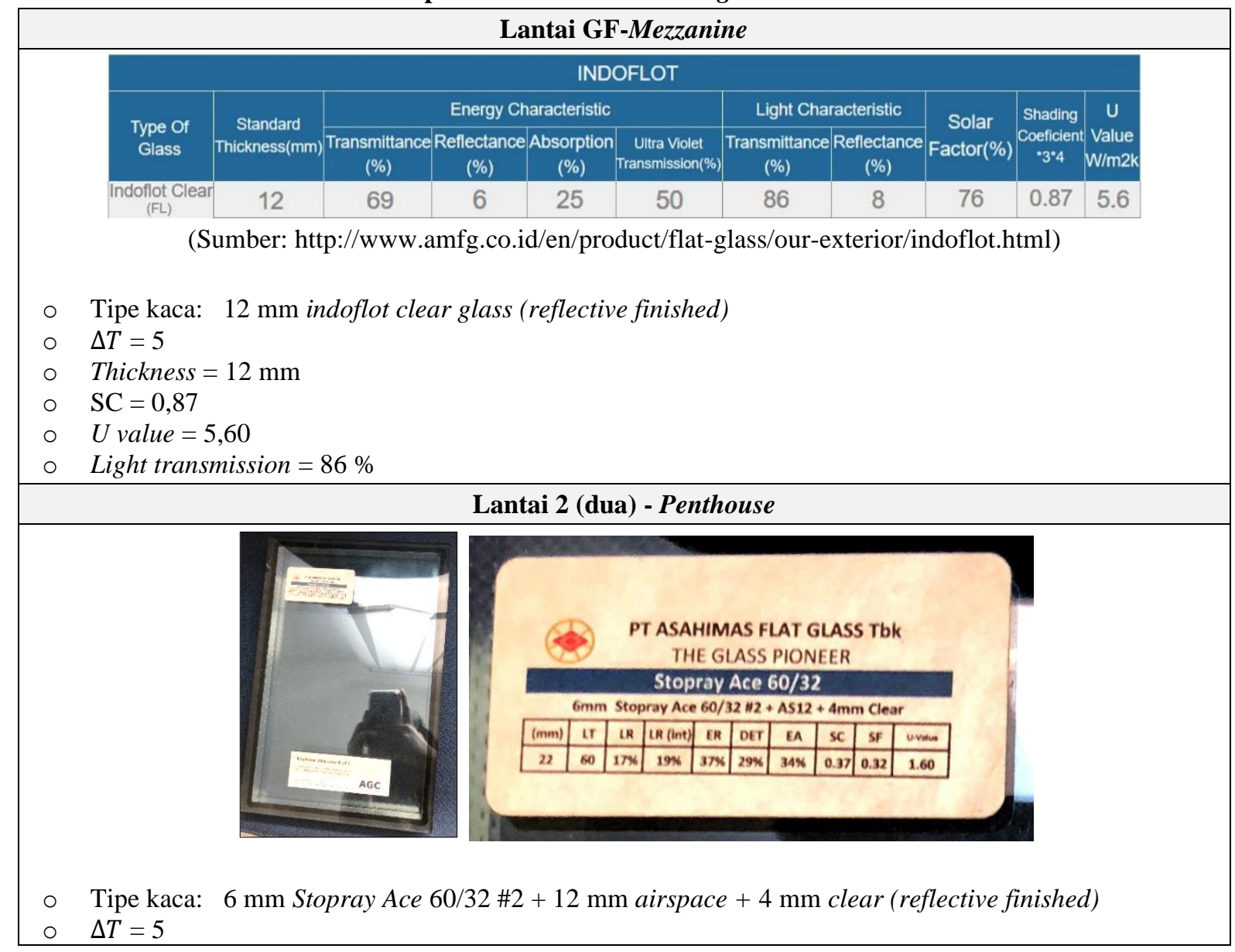




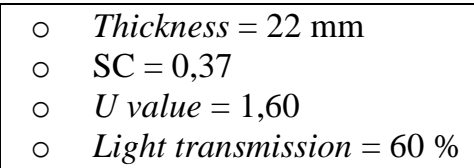

Berikut adalah nilai OTTV dan intensitas pencahayaan alami hasil modifikasi 1.

Tabel 7 Analisis Nilai OTTV Hasil Modifikasi 1

\begin{tabular}{|c|c|c|c|c|c|c|c|}
\hline \multirow{2}{*}{ Lantai } & \multicolumn{3}{|c|}{ Kondisi Eksisting } & \multicolumn{3}{c|}{ Modifikasi 1 } & \multirow{2}{*}{$\Delta$ OTTV } \\
\cline { 2 - 7 } & $\begin{array}{c}\boldsymbol{U} \\
\text { value }\end{array}$ & $\begin{array}{c}\text { Shading } \\
\text { Coefficient }\end{array}$ & $\begin{array}{c}\text { Nilai } \\
\text { OTTV } \\
\left(\mathbf{W} / \mathbf{m}^{2}\right)\end{array}$ & $\begin{array}{c}\boldsymbol{U} \\
\text { value }\end{array}$ & $\begin{array}{c}\text { Shading } \\
\text { Coefficient }\end{array}$ & $\begin{array}{c}\text { Nilai } \\
\text { OTTV } \\
\left(\mathbf{W} / \mathbf{m}^{2}\right)\end{array}$ & \multirow{2}{*}{} \\
\hline $\mathrm{M}$ & 5,60 & 0,83 & 29,56 & 5,60 & 0,87 & 29,79 & 0,23 \\
\hline 2 & 1,80 & 0,26 & 24,26 & 1,60 & 0,37 & 31,37 & 7,11 \\
\hline 11 & 1,80 & 0,26 & 18,17 & 1,60 & 0,37 & 22,70 & 4,53 \\
\hline 21 & 1,80 & 0,26 & 29,85 & 1,60 & 0,37 & 39,32 & 9,47 \\
\hline $\mathrm{P}$ & 1,80 & 0,26 & 34,74 & 1,60 & 0,37 & 45,84 & 11,10 \\
\hline
\end{tabular}

Tabel 8 Analisis Intensitas Pencahayaan Alami Hasil Modifikasi 1

\begin{tabular}{|c|c|c|c|c|c|}
\hline \multirow[b]{2}{*}{ Lantai } & \multicolumn{2}{|c|}{ Kondisi Eksisting } & \multicolumn{2}{|c|}{ Modifikasi 1} & \multirow[b]{2}{*}{$\begin{array}{c}\Delta \text { Rasio Luas } \\
\text { Lantai Kerja } \\
\text { dengan } \\
\text { Iluminansi } \\
\geq 300 \text { lux } \\
\text { terhadap Luas } \\
\text { Lantai Kerja } \\
\text { Keseluruhan } \\
(\%)\end{array}$} \\
\hline & $\begin{array}{c}\text { Light } \\
\text { Tranmission } \\
(\%)\end{array}$ & $\begin{array}{c}\text { Rasio Luas } \\
\text { Lantai Kerja } \\
\text { dengan } \\
\text { Iluminansi } \\
\geq 300 \text { lux } \\
\text { terhadap Luas } \\
\text { Lantai Kerja } \\
\text { Keseluruhan (\%) }\end{array}$ & $\begin{array}{c}\text { Light } \\
\text { Transmission } \\
(\%)\end{array}$ & $\begin{array}{c}\text { Rasio Luas } \\
\text { Lantai Kerja } \\
\text { dengan } \\
\text { Iluminansi } \\
\geq 300 \text { lux } \\
\text { terhadap Luas } \\
\text { Lantai Kerja } \\
\text { Keseluruhan (\%) }\end{array}$ & \\
\hline M & 78 & 17,52 & 86 & 30,41 & 12,89 \\
\hline 2 & 35 & 6,91 & 60 & 34,02 & 27,11 \\
\hline 11 & 35 & 7,74 & 60 & 33,70 & 25,96 \\
\hline 21 & 35 & 8,55 & 60 & 36,45 & 27,90 \\
\hline $\mathrm{P}$ & 35 & 9,30 & 60 & 43,58 & 34,28 \\
\hline
\end{tabular}

Berdasarkan hasil modifikasi 1 di atas, dapat disimpulkan bahwa: a) pemilihan material glazing memiliki pengaruh besar terhadap nilai OTTV maupun intensitas pencahayaan alami yang masuk, b) nilai $U$ value dan shading coefficient yang lebih rendah akan menurunkan nilai OTTV, serta c) Nilai light transmission yang lebih tinggi akan meningkatkan intensitas pencahayaan alami yang masuk.

\subsubsection{MODIFIKASI 2: PERUBAHAN MATERIAL GLAZING + PENAMBAHAN BIDANG MASIF}

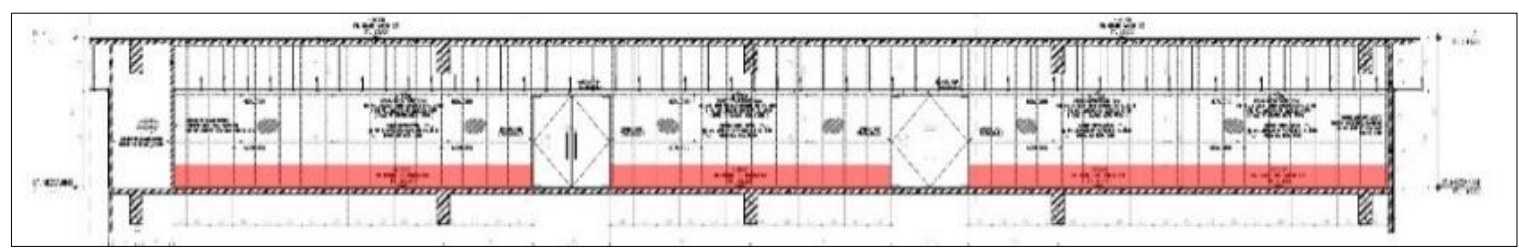

Gambar 8 Penambahan Bidang Masif 
Perubahan material glazing dapat meningkatkan masuknya intensitas pencahayaan alami dengan pemilihan material yang memiliki ligh transmittance lebih tinggi daripada material eksisting. Namun, perubahan ini dapat juga meningkatkan nilai OTTV karena nilai shading coefficient yang lebih tinggi dan $U$ value yang lebih rendah. Oleh karena itu, cara lain yang dapat diterapkan ialah melakukan penambahan bidang masif pada area dekat lantai, karena pada ketinggian ini cahaya alami tidak dapat masuk ke dalam ruangan dengan efektif (hanya memanfaatkan pantulan lantai). Luas penambahan bidang masif ini diambil dari hasil perhitungan nilai OTTV agar mencapai $33,25 \mathrm{~W} / \mathrm{m}^{2}$ (memperoleh poin maksimal berdasarkan standar Greenship).

Material bidang masif yang digunakan adalah ALPOLIC®/fr-RF, yaitu Aluminium Composite Material (ACM) yang reflektif dengan inti mineral yang tidak mudah terbakar, biasanya digunakan sebagai aplikasi dinding langit-langit atau interior. Material ini dipilih karena finishing permukaannya yang reflektif menyerupai kaca sehingga tidak mempengaruhi estetika fasad bangunan eksisting. ALPOLIC $® / f r-R F$ terdiri dari inti yang diisi mineral yang tidak mudah terbakar, dengan finishing pada kedua sisi dengan paduan aluminium tebal 0,5 $\mathrm{mm}$. Dimensi panel ALPOLIC®/fr-RF ialah $1220 \mathrm{~mm}$ x $2440 \mathrm{~mm}$ dengan tebal $3 \mathrm{~mm}$. Nilai transmitansi termal ( $U$ value) ALPOLIC $® / f r-R F$ adalah $0,95 \mathrm{~W} / \mathrm{m}^{2} \mathrm{~K}$.

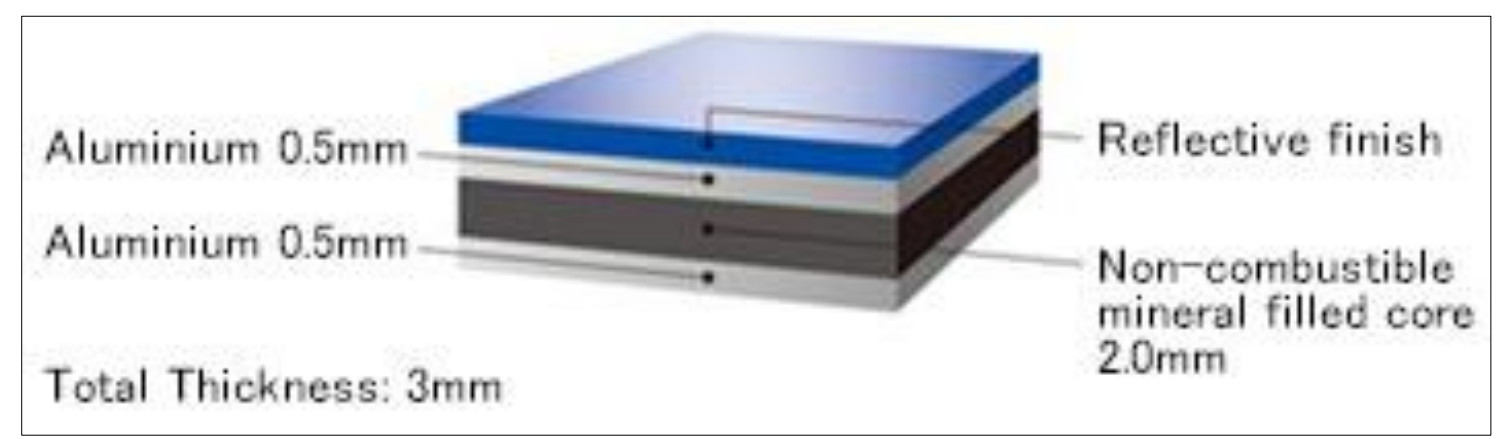

Gambar 9 ALPOLIC®/fr-RF

(Sumber: http://www.alpolic.com/alpolic-intl/product_fr-rf.html)

Berdasarkan hasil modifikasi 2 dapat disimpulkan bahwa: a) penambahan bidang masif dapat menurunkan nilai OTTV karena perubahan Window to Wall Ratio (WWR), sehingga nilai konduksi melalui kaca dan radiasi melalui kaca berkurang jauh lebih besar daripada kenaikan nilai konduksi melalui dinding, b) keberadaan bidang masif pada bagian dekat lantai memiliki pengaruh yang cukup signifikan terhadap penurunan intensitas pencahayaan alami yang masuk, karena dapat menghalangi cahaya yang datang langsung maupun cahaya yang dipantulkan melalui kantilever di sisi depan fasad, serta c) nilai OTTV juga dapat diturunkan dengan dengan menambah elemen yang dapat memberikan shading pada desain selubung bangunan sehingga dapat menurunkan nilai shading coefficient effective.

Tabel 9 Kombinasi Penambahan Bidang Masif dan SCeff untuk Mencapai Nilai OTTV 33,25W/m²

\begin{tabular}{|c|c|c|c|c|c|}
\hline \multirow{2}{*}{ Lantai } & \multicolumn{2}{|c|}{ Modifikasi 2a } & \multicolumn{2}{|c|}{ Modifikasi 2b } & Nilai OTTV \\
\cline { 2 - 5 } & SCeff & $\begin{array}{c}\text { Tinggi Penambahan } \\
\text { Bidang Masif (meter) }\end{array}$ & SCeff & $\begin{array}{c}\text { Tinggi Penambahan Bidang } \\
\text { Masif (meter) }\end{array}$ & $\begin{array}{c}\text { (W/m } \\
\text { (21 }\end{array}$ \\
\hline P & 0,94 & 0,88 & 0,85 & 0,65 & 33,25 \\
\hline
\end{tabular}




\subsubsection{MODIFIKASI 3: PERUBAHAN WARNA MATERIAL LANTAI, SECONDARY SKIN, DAN PLAFON}

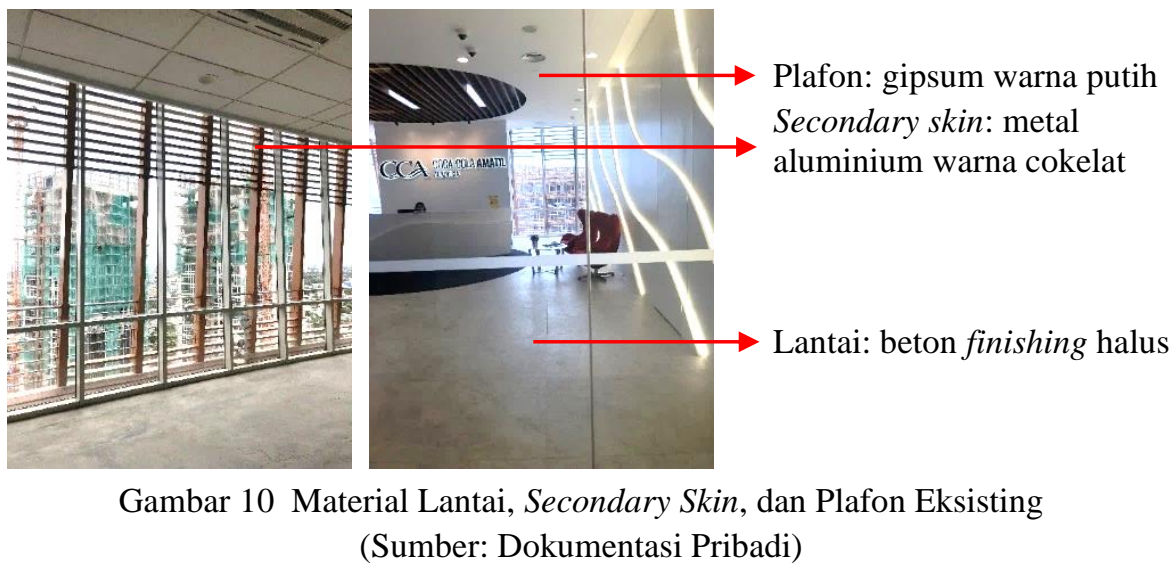

Warna material juga dapat mempengaruhi intensitas pencahayaan alami yang diterima di dalam bangunan karena adanya perbedaan nilai reflektansi dari masing-masing material. Material dengan warna terang dan mengkilap ( glossy) memiliki tingkat reflektansi yang lebih tinggi dibandingkan dengan warna gelap dan tidak mengkilap (matte). Dari keempat material di atas, material plafon dan dinding sudah menggunakan material dengan warna terang yang baik untuk merefleksikan cahaya. Namun, material lantai dengan beton finishing halus masih dapat dioptimalkan lagi dengan diubah menjadi lantai marmer putih mengkilap. Sedangkan warna material secondary skin tidak dapat diubah lagi karena warna cokelat tersebut merupakan bagian dari konsep bangunan. digunakan.

Berikut adalah spesifikasi material eksisting dan material untuk modifikasi yang

Tabel 10 Spesifikasi Material Selubung Bangunan Eksisting dan Modifikasi 3

\begin{tabular}{|l|l|}
\hline \multicolumn{1}{|c|}{ Eksisting } & \multicolumn{1}{c|}{ Modifikasi 3 } \\
\hline Material lantai: beton finishing halus & Material lantai: marmer polished carrara white \\
Reflectance: $76 \%$ & marble \\
Roughness: $40 \%$ & Reflectance: $85 \%$ \\
& Roughness: $5 \%$ \\
\hline Material secondary skin: metal aluminium warna & Material secondary skin: metal aluminium warna \\
cokelat & cokelat \\
Reflectance: $94 \%$ & Reflectance: $94 \%$ \\
Roughness: $10 \%$ & Roughness: $10 \%$ \\
\hline Material plafon: gipsum warna putih & Material plafon: gipsum warna putih \\
Reflectance: $84 \%$ & Reflectance: $84 \%$ \\
Roughness: $30 \%$ & Roughness: $30 \%$ \\
\hline Material dinding: gipsum/bata cat putih & Material dinding: gipsum/bata cat putih \\
Reflectance: $84 \%$ & Reflectance: $84 \%$ \\
Roughness: $30 \%$ & Roughness: $30 \%$ \\
\hline
\end{tabular}

Berdasarkan hasil modifikasi 3 dapat disimpulkan bahwa penggantian warna material lantai menjadi lebih terang dan reflektif (glossy) dapat meningkatkan intensitas pencahayaan alami yang masuk karena dapat membantu merefleksikan cahaya dengan lebih baik. 
Tabel 11 Analisis Pengaruh Penggantian Material Lantai

\begin{tabular}{|c|c|c|c|c|c|c|}
\hline \multirow{3}{*}{ Lantai } & \multicolumn{3}{|c|}{$\begin{array}{c}\text { Kondisi Eksisting: } \\
\text { Beton Finishing Halus }\end{array}$} & \multicolumn{3}{c|}{ Marmer Polished Carrara White Marble } \\
\cline { 2 - 6 } & $\begin{array}{c}\text { Reflec- } \\
\text { tance }\end{array}$ & $\begin{array}{c}\text { Rough- } \\
\text { ness }\end{array}$ & $\begin{array}{c}\text { Rasio Luas Lantai } \\
\text { Kerja dengan } \\
\text { Iluminansi 300 lux } \\
\text { terhadap Luas } \\
\text { Lantai Kerja } \\
\text { Keseluruhan (\%) }\end{array}$ & $\begin{array}{c}\text { Rasio Luas Lantai } \\
\text { Kerja dengan } \\
\text { Rance } \\
\text { Iluminansi 300 lux } \\
\text { terhadap Luas Lantai } \\
\text { Kerja Keseluruhan } \\
(\boldsymbol{\%})\end{array}$ \\
\hline $\mathrm{M}$ & 75 & 40 & 17,52 & 85 & 5 & 21,13 \\
\hline 2 & 75 & 40 & 6,91 & 85 & 5 & 9,94 \\
\hline 11 & 75 & 40 & 7,74 & 85 & 5 & 11,05 \\
\hline 21 & 75 & 40 & 8,55 & 85 & 5 & 13,48 \\
\hline $\mathrm{P}$ & 75 & 40 & 9,30 & 85 & 5 & 13,95 \\
\hline
\end{tabular}

\subsubsection{HASIL OPTIMASI DESAIN}

Optimasi redesain selubung bangunan untuk pemenuhan standar intensitas pencahayaan alami dan nilai OTTV pada kantor South Quarter Jakarta berdasarkan kriteria Greenship adalah sebagai berikut.

Tabel 12 Optimasi Redesain Selubung Bangunan Kantor South Quarter

\begin{tabular}{|c|c|c|c|c|c|c|}
\hline \multirow[t]{2}{*}{ No } & \multirow[t]{2}{*}{$\mathbf{L}$} & \multirow[t]{2}{*}{ Upaya Optimasi redesain } & \multicolumn{2}{|c|}{$\begin{array}{l}\text { Rasio Luas } \\
\text { Lantai Kerja } \\
\text { dengan } \\
\text { Iluminansi } \geq \\
300 \text { lux } \\
\text { terhadap Luas } \\
\text { Lantai Kerja } \\
\text { Keseluruhan } \\
(\%)\end{array}$} & \multicolumn{2}{|c|}{$\begin{array}{c}\text { Nilai OTTV } \\
(\text { Watt/m²) }\end{array}$} \\
\hline & & & Eks & Opt & Eks & Opt \\
\hline 1. & M & $\begin{array}{l}\text { a. Penggantian material kaca menjadi } 12 \mathrm{~mm} \\
\text { indoflot clear glass (reflective finished). } \\
\text { b. Penggantian material lantai menjadi marmer } \\
\text { polished carrara white marble. }\end{array}$ & 17,52 & 32,36 & 29,56 & 29,79 \\
\hline 2. & 2 & $\begin{array}{l}\text { a. Penggantian material kaca menjadi } 6 \mathrm{~mm} \text { Stopray } \\
\text { Ace } 60 / 32 \# 2+12 \mathrm{~mm} \text { airspace }+4 \mathrm{~mm} \text { clear } \\
\text { (reflective finished). } \\
\text { b. Penggantian material lantai menjadi marmer } \\
\text { polished carrara white marble. }\end{array}$ & 6,91 & 37,62 & 24,26 & 31,37 \\
\hline 3. & 11 & $\begin{array}{l}\text { a. Penggantian material kaca menjadi } 6 \mathrm{~mm} \text { Stopray } \\
\text { Ace } 60 / 32 \# 2+12 \mathrm{~mm} \text { airspace }+4 \mathrm{~mm} \text { clear } \\
\text { (reflective finished).. } \\
\text { b. Penggantian material lantai menjadi marmer } \\
\text { polished carrara white marble. }\end{array}$ & 7,74 & 36,59 & 18,17 & 22,70 \\
\hline 4. & 21 & $\begin{array}{l}\text { a. Penggantian material kaca menjadi Stopray } \\
\text { Vision } 50(1), 6 \mathrm{~mm} \text { Stopray } \# 2+12 \mathrm{~mm}+6 \mathrm{~mm} \\
\text { clear }(\text { reflective finished).. } \\
\text { b. Penggantian material lantai menjadi marmer } \\
\text { polished carrara white marble. } \\
\text { c. Penambahan elemen secondary skin untuk } \\
\text { menurunkan SCeff menjadi 0,85. } \\
\text { d. Penambahan bidang masif ALPOLIC@/fr-RF } \\
\text { setinggi 0,65 meter. }\end{array}$ & 8,55 & 30,47 & 29,85 & 33,23 \\
\hline
\end{tabular}




\begin{tabular}{|c|c|c|c|c|c|c|}
\hline & & $\begin{array}{l}\text { e. Penambahan light shelf dengan material panel } \\
\text { metal (reflectance: } 95 \% \text { ) sepanjang } 90 \mathrm{~cm} \text {. }\end{array}$ & & & & \\
\hline 5. & $\mathrm{P}$ & $\begin{array}{l}\text { a. Penggantian material kaca menjadi Stopray } \\
\text { Vision } 50(1), 6 \mathrm{~mm} \text { Stopray } \# 2+12 \mathrm{~mm}+6 \mathrm{~mm} \\
\text { clear (reflective finished).. } \\
\text { b. Penggantian material lantai menjadi marmer } \\
\text { polished carrara white marble. } \\
\text { c. Penambahan elemen secondary skin untuk } \\
\text { menurunkan SCeff menjadi 0,82. } \\
\text { d. Penambahan bidang masif ALPOLIC®/fr-RF } \\
\text { setinggi } 1,15 \text { meter. } \\
\text { e. Penambahan light shelf dengan material panel } \\
\text { metal (reflectance: } 95 \% \text { ) sepanjang } 120 \mathrm{~cm} .\end{array}$ & 9,30 & 30,07 & 34,74 & 33,09 \\
\hline
\end{tabular}

Keterangan: $\mathrm{L}=$ lantai, $\quad$ Eks = eksisting, Opt = optimasi

Tabel 13 Rangkuman Perbandingan Optimasi Redesain Selubung Bangunan Kantor

\begin{tabular}{|c|c|c|c|c|c|c|c|c|c|}
\hline \multirow{2}{*}{ Lantai } & \multicolumn{5}{|c|}{ Upaya Optimasi Redesain } & \multirow{2}{*}{$\mathrm{L}_{\mathrm{e}}(\%)$} & \multirow{2}{*}{$\mathrm{L}_{0}(\%)$} & \multirow{2}{*}{$\begin{array}{l}\text { OTTVe }_{\text {e }} \\
\left(\mathrm{W} / \mathbf{m}^{2}\right)\end{array}$} & \multirow{2}{*}{$\begin{array}{l}\text { OTTV }_{o} \\
\left(\mathbf{W} / \mathbf{m}^{2}\right)\end{array}$} \\
\hline & $\mathbf{a}$ & b & c & d & e & & & & \\
\hline M & $\begin{array}{c}\bullet \\
12 \mathrm{IC} \\
\end{array}$ & $\begin{array}{c}\bullet \\
\mathrm{MP}\end{array}$ & & & & 17,52 & 32,36 & 29,56 & 29,79 \\
\hline 2 & $\begin{array}{c}\bullet \\
22 \mathrm{SA} \\
\end{array}$ & $\begin{array}{c}\bullet \\
\mathrm{MP}\end{array}$ & & & & 6,91 & 37,62 & 24,26 & 31,37 \\
\hline 11 & $\begin{array}{c}\bullet \\
22 \mathrm{SA}\end{array}$ & $\begin{array}{c}\bullet \\
\mathrm{MP}\end{array}$ & & & & 7,74 & 36,59 & 18,17 & 22,70 \\
\hline 21 & $\stackrel{\bullet}{24 \mathrm{SV}}$ & $\begin{array}{c}\bullet \\
\mathrm{MP}\end{array}$ & $\stackrel{\bullet}{0,85}$ & $\stackrel{\bullet}{0,65 \mathrm{~m}}$ & $\begin{array}{c}\bullet \\
90 \mathrm{~cm}\end{array}$ & 8,55 & 30,47 & 29,85 & 33,23 \\
\hline $\mathrm{P}$ & $\begin{array}{c}\bullet \\
24 \mathrm{SV}\end{array}$ & $\begin{array}{c}\bullet \\
\mathrm{MP}\end{array}$ & $\begin{array}{c}\bullet \\
0,82\end{array}$ & $\begin{array}{c}\bullet \\
1,15 \mathrm{~m}\end{array}$ & $\begin{array}{c}\bullet \\
120 \mathrm{~cm}\end{array}$ & 9,30 & 30,07 & 34,74 & 33,09 \\
\hline
\end{tabular}

Keterangan:

a = penggantian material kaca untuk meningkatkan light transmission serta menurunkan/meningkatkan U value dan shading coefficient

$\mathrm{b} \quad=$ penggantian material lantai untuk meningkatkan nilai reflectance material

$\mathrm{c} \quad=$ penambahan elemen secondary skin untuk menurunkan SCeff

$\mathrm{d}=$ penambahan bidang masif ALPOLIC®/fr-RF untuk menurunkan nilai WWR

e $\quad=$ penambahan light shelf untuk membantu memasukkan cahaya matahari

$\mathrm{L}_{\mathrm{e}} \quad=$ rasio luas lantai kerja dengan iluminansi 300 lux terhadap luas lantai kerja keseluruhan eksisting (dalam \%)

$\mathrm{L}_{\mathrm{o}} \quad=\quad$ rasio luas lantai kerja dengan iluminansi 300 lux terhadap luas lantai kerja keseluruhan hasil Optimasi redesain (dalam \%)

OTTV $_{\mathrm{e}}=$ nilai OTTV eksisting $\left(\right.$ dalam $\left.\mathrm{W} / \mathrm{m}^{2}\right)$

OTTV $_{\mathrm{o}}=$ nilai OTTV hasil Optimasi redesain $\left(\right.$ dalam $\mathrm{W} / \mathrm{m}^{2}$ )

$12 \mathrm{IC}=12 \mathrm{~mm}$ indoflot clear glass (reflective finished).

$22 \mathrm{SA}=22 \mathrm{~mm}$ Stopray Ace $(6 \mathrm{~mm}$ Stopray Ace 60/32 \#2 + $12 \mathrm{~mm}$ airspace $+4 \mathrm{~mm}$ clear) (reflective finished).

$24 \mathrm{SV}=24 \mathrm{~mm}$ Stopray Vision 50(1) $(6 \mathrm{~mm}$ Stopray \#2+12 mm+6 mm clear) (reflective finished)

MP = marmer polished carrara white marble

\section{KESIMPULAN}

Dari berbagai simulasi yang dilakukan untuk mendapatkan optimasi redesain selubung bangunan di atas, dapat disimpulkan bahwa terdapat berbagai faktor yang dapat meningkatkan intensitas pencahayaan alami maupun menurunkan nilai OTTV. Berikut adalah faktor yang 
dapat mempengaruhi upaya optimasi desain selubung bangunan kantor South Quarter untuk pemenuhan standar intensitas pencahayaan alami berdasarkan kriteria Greenship: a) light transmission material glazing, b) material lantai, plafon, dan dinding, c) light shelf, dan d) keberadaan bidang masif. Selain itu, berikut ini adalah yang dapat mempengaruhi upaya optimasi desain selubung bangunan kantor South Quarter untuk pemenuhan standar nilai OTTV berdasarkan kriteria Greenship: a) $U$ value dan shading coefficient material glazing, b) perubahan WWR karena penambahan bidang masif, serta c) pembayangan pada selubung bangunan.

Light transmission material glazing. Material glazing dengan nilai light transmission yang lebih tinggi dapat meningkatkan intensitas pencahayaan alami yang masuk ke dalam bangunan. Sebaliknya, material glazing dengan light transmission yang lebih rendah dapat menurunkan intensitas pencahayaan alami yang masuk ke dalam bangunan. Setiap lantai pada kantor South Quarter Jakarta mempunyai kebutuhan yang berbeda-beda, hal itu terlihat dari hasil simulasi. Penggunaan kaca $12 \mathrm{~mm}$ indoflot clear glass efektif untuk lantai mezzanine karena light transmission tipe kaca ini relatif tinggi (86\%) sehingga sesuai untuk diterapkan pada desain selubung bangunan lantai mezzanine yang mempunyai pembayangan cukup panjang dari kantilever di atasnya. Penggunaan kaca $22 \mathrm{~mm}$ Stopray Ace $(6 \mathrm{~mm}$ Stopray Ace $60 / 32 \# 2+12 \mathrm{~mm}$ airspace $+4 \mathrm{~mm}$ clear) efektif untuk lantai 2 (dua) dan 11 (sebelas), sedangkan penggunaan kaca $24 \mathrm{~mm}$ Stopray Vision 50(1) (6 mm Stopray \#2 + $12 \mathrm{~mm}$ airspace + $6 \mathrm{~mm}$ clear) efektif untuk lantai penthouse. Kedua tipe kaca tersebut adalah kaca double glass dengan insulasi airspace di antara kedua kacanya sehingga memiliki light transmission yang relatif rendah $(<50 \%)$. Meskipun demikian, kedua tipe kaca ini cocok untuk diterapkan pada lantai 2, 11, 21, dan penthouse karena karakteristik desain selubung bangunan pada keempat sampel lantai ini memiliki WWR 100\% dan koefisien pembayangan yang relatif kecil.

Material lantai, plafon, dan dinding. Material lantai, plafon, dan dinding dengan warna yang lebih terang dan permukaan reflektif (nilai material reflectance lebih tinggi) dapat meningkatkan intensitas pencahayaan alami yang masuk karena dapat membantu merefleksikan cahaya dengan lebih baik. Sedangkan material lantai, plafon, dan dinding dengan warna yang lebih gelap dan permukaan tidak reflektif (nilai material reflectance lebih rendah) dapat menurunkan intensitas pencahayaan alami yang masuk. Marmer polished carrara white marble mempunyai nilai reflektansi material sebesar $85 \%$, yang lebih tinggi daripada material eksisting beton finishing halus dengan nilai reflektansi sebesar $76 \%$. Dari hasil simulasi, perubahan nilai reflektansi material lantai sebesar $9 \%$ (menjadi lebih tinggi) dapat meningkatkan rasio luas lantai kerja dengan iluminansi $\geq 300$ lux terhadap luas lantai kerja keseluruhan sebesar 3,03-4,93\%.

Light shelf. Penambahan light shelf dapat meningkatkan tingkat kemerataan cahaya karena light shelf dapat membantu memasukkan pencahayaan alami pada area yang awalnya tidak terjangkau oleh cahaya matahari langsung. Dengan demikian, luas lantai kerja dengan iluminansi 300 lux juga dapat meningkat. Penambahan light shelf dengan material metal (reflectance: $95 \%$ ) sepanjang $90 \mathrm{~cm}$ pada lantai 21 (dua puluh satu) dapat meningkatkan rasio luas lantai kerja dengan iluminansi $\geq 300$ lux terhadap luas lantai kerja keseluruhan sebesar $1,68 \%$, sedangkan penambahan light shelf dengan material yang sama sepanjang $120 \mathrm{~cm}$ pada lantai penthouse dapat meningkatkan rasio luas lantai kerja dengan iluminansi $\geq 300$ lux terhadap luas lantai kerja keseluruhan sebesar 4,49\%.

Bidang masif. Keberadaan bidang masif pada bagian dekat lantai memiliki pengaruh yang cukup signifikan terhadap penurunan intensitas pencahayaan alami yang masuk, karena dapat menghalangi cahaya yang datang langsung maupun cahaya yang dipantulkan melalui kantilever di sisi depan fasad. Penambahan bidang masif pada lantai 21 (dua puluh satu) setinggi $90 \mathrm{~cm}$ dapat mengurangi rasio luas lantai kerja dengan iluminansi $\geq 300$ lux terhadap luas lantai kerja keseluruhan sebesar 18,79\% (dari 36,45\% menjadi 17,66 \%), sedangkan 
penambahan bidang masif pada lantai penthouse setinggi $160 \mathrm{~cm}$ dapat mengurangi rasio luas lantai kerja dengan iluminansi $\geq 300$ lux terhadap luas lantai kerja keseluruhan sebesar 38,19\% (dari 43,58\% menjadi 5,39\%).

$U$ value dan shading coefficient material glazing. Material glazing dengan nilai $U$ value dan shading coefficient yang lebih rendah akan menurunkan nilai OTTV, sedangkan material glazing dengan nilai $U$ value dan shading coefficient yang lebih tinggi akan meningkatkan nilai OTTV. Peningkatan nilai shading coefficient pada lantai mezzanine sebesar 0,04 dapat meningkatkan nilai OTTV sebesar $0,23 \mathrm{Watt} / \mathrm{m}^{2}$, sedangkan penurunan nilai $U$ value sebesar 0,20 disertai dengan peningkatan nilai shading coefficient sebesar 0,11 pada keempat lantai sampel lainnya dapat meningkatkan nilai OTTV sebesar 4,53-11,10 Watt $/ \mathrm{m}^{2}$.

Perubahan WWR karena penambahan bidang masif. Penambahan bidang masif dapat dapat menurunkan nilai OTTV karena perubahan Window to Wall Ratio (WWR), sehingga nilai konduksi melalui kaca dan radiasi melalui kaca berkurang jauh lebih besar daripada kenaikan nilai konduksi melalui dinding. Penambahan bidang masif pada lantai 21 (dua puluh satu) setinggi $88 \mathrm{~cm}$ dapat menurunkan nilai OTTV sebesar $6,07 \mathrm{Watt} / \mathrm{m}^{2}$ (dari $39,32 \mathrm{Watt} / \mathrm{m}^{2}$ menjadi $33,25 \mathrm{Watt} / \mathrm{m}^{2}$ ), sedangkan penambahan bidang masif pada lantai penthouse setinggi $158 \mathrm{~cm}$ dapat menurunkan nilai OTTV sebesar 12,59 Watt $/ \mathrm{m}^{2}$ (dari 45,84 Watt $/ \mathrm{m}^{2}$ menjadi 33,25 Watt $/ \mathrm{m}^{2}$ ).

Elemen pembayangan. Nilai OTTV juga dapat diturunkan dengan dengan menambah elemen yang dapat memberikan shading pada desain selubung bangunan sehingga dapat menurunkan nilai shading coefficient effective. Semakin banyak elemen yang dapat memberikan pembayangan pada selubung bangunan, nilai OTTV akan semakin rendah. Sebaliknya, semakin sedikit elemen yang dapat memberikan pembayangan pada selubung bangunan, nilai OTTV akan semakin tinggi. Penurunan nilai shading coefficient effective sebesar 0,09 (dari 0,94 menjadi 0,85) pada lantai 21 (dua puluh satu) dapat membantu mengurangi kebutuhan penambahan bidang masif sebesar $23 \mathrm{~cm}$ (dari $88 \mathrm{~cm}$ menjadi $65 \mathrm{~cm}$ ) untuk menurunkan nilai OTTV (untuk mencapai 33,25 Watt $/ \mathrm{m}^{2}$ ), sedangkan penurunan nilai shading coefficient effective sebesar 0,14 (dari 0,96 menjadi 0,82) pada lantai penthouse dapat membantu mengurangi kebutuhan penambahan bidang masif sebesar $45 \mathrm{~cm}$ (dari $158 \mathrm{~cm}$ menjadi $113 \mathrm{~cm}$ ) untuk menurunkan nilai OTTV sesuai dengan standar.

Dengan demikian, optimasi redesain selubung bangunan untuk pemenuhan standar intensitas pencahayaan alami dan nilai OTTV pada kantor South Quarter Jakarta berdasarkan kriteria Greenship dapat dicapai dengan dengan menerapkan 2 (dua) sampai 5 (lima) perlakuan di atas untuk meningkatkan intensitas pencahayaan alami dengan tetap menjaga nilai OTTV sesuai standar Greenship.

\section{DAFTAR PUSTAKA}

7group dan Bill Reed. 2009. The Integrative Design Guide to Green Building. New Jersey: John Wiley \& Sons, Inc.

Bonda, Penny dan Katie Sosnowchik. 2007. Sustainable Commercial Interiors. New Jersey: John Wiley \& Sons, Inc.

Browning, William D., dkk. 2006. Green Office Buildings, A Practical Guide to Development. Washington D.C.: Urban Land Institute.

Building and Construction Authority. 2010. Building Planning and Massing, Green Building Platinum Series.

Direktorat Jenderal Ciptakarya. 1981. Penerangan Alami Siang Hari dari Bangunan. Bandung: Yayasan Lembaga Penyelidikan Masalah Bangunan.

Haryandaru, Dipa. "South Quarter, Ruang yang Inspiratif” diakses dari http://www.rei.or.id/newrei/berita-southquarter-ruang-yang-inspiratif.html, pada tanggal 10 Januari 2018.

Keputusan Menteri Kesehatan Republik Indonesia Nomor 1405/MENKES/SK/XI/2002 tentang Persyaratan Kesehatan Lingkungan Kerja Perkantoran dan Industri. 
Loekita, Sandra. 2006. “Analisis Konservasi Energi Melalui Selubung Bangunan” dalam Dimensi Teknik Sipil 8(2): 93-98, September.

Rahmadiina, Fitri, dkk. TT. "Optimalisasi Kinerja Pencahayaan Alami pada Kantor (Studi Kasus: Plasa Telkom Blimbing Malang)". Malang: Universitas Brawijaya.

Sholichin, Yurio Provandi. 2012. "Pengaruh Material Dinding terhadap Nilai OTTV pada Berbagai Orientasi Bangunan". Depok: Universitas Indonesia.

SNI 03-6389-2000 Konservasi Energi Selubung Bangunan pada Bangunan Gedung.

Sutanto, E.B. Handoko. 2017. Prinsip-Prinsip Pencahayaan Buatan Dalam Arsitektur. Sleman: Penerbit PT Kanisius.

US Energy Information and Administration, "Energy Consumption Estimates by Sector", diakses dari https://www.eia.gov/consumption/, pada tanggal 26 Januari 2018. 